\title{
Breast cancer literacy among higher secondary students: results from a cross-sectional study in Western Nepal
}

Parash Mani Bhandari ${ }^{1 *}$, Kiran Thapa ${ }^{1}$, Sarmila Dhakal ${ }^{1}$, Shristi Bhochhibhoya ${ }^{1}$, Rashmi Deuja ${ }^{1}$, Pawan Acharya ${ }^{2}$ and Shiva Raj Mishra ${ }^{3,4}$

\begin{abstract}
Background: Being the most common cancer among women worldwide, it is vital to be well-aware of breast cancer risk factors, symptoms and curability. However, few studies have reported breast cancer literacy in students using a validated instrument.

Methods: A cross-sectional study was conducted among students of grades 11 and 12 from eleven higher secondary schools, one selected randomly from each ilaka of Parbat district. Questionnaire with modified Comprehensive Breast Cancer Knowledge Test was self-administered to 516 students. Knowledge score was categorized into two categories: 'good knowledge' and 'poor knowledge' taking median score as the cut-off. Chi-square test was used to determine difference in knowledge by socio-demographic factors, including gender.
\end{abstract}

Results: Only $4.8 \%$ of the students responded correctly to at least half of the items, and $1.4 \%$ did not respond correctly to any of the items on risk factors and curability. Physical exercise was identified as a protective factor of breast cancer by $62.4 \%$ of the students. Presence of noncancerous breast lumps (56.6\%) and being overweight (36.4\%) were recognized as the risk factors. Knowledge of lumpectomy and radiation therapy for treatment of breast cancer was reported by $42.8 \%$ of students, while only $39.0 \%$ were aware of the availability of treatment therapies other than mastectomy. Males were significantly better informed than females $\left(x^{2}=4.02, p=0.045\right)$. Pain in the breast $(23.3 \%)$, change in the shape of the breast (20.0 \%) and discharge of pus (14.1\%) were the three most commonly recognized symptoms. Nearly one in two (47.1\%) students indicated that the school curriculum inadequately informed them on breast cancer.

Conclusion: Our study demonstrates poor knowledge on breast cancer risk factors, symptoms and curability among higher secondary school students in Western Nepal. Still, several myths regarding breast cancer persist. Half of the students had the perception that school curriculum inadequately informed them on breast cancer. Future studies should aim at the measures necessary to address the inadequate knowledge, along with the perceived gap in school curriculum.

Keywords: Breast cancer, Cross-sectional studies, Risk factors, Knowledge, Students, Nepal

\footnotetext{
* Correspondence: parashmanibhandari@gmail.com

${ }^{1}$ Maharajgunj Medical Campus, Institute of Medicine, Tribhuvan University,

Kathmandu, Nepal

Full list of author information is available at the end of the article
} 


\section{Background}

Global statistics suggest that breast cancer is the most frequently diagnosed and a leading cause of death in women [1]. In South Asia, it is the most common malignancy among women [2], is detected more often in younger females and at a more advanced stage as compared to females of other regions [1]. This is partly due to inaccessibility to screening and diagnostic facilities, illiteracy, lack of prompt decision making and females being uninformed about early detection of breast cancer [3]. Preparedness and regular monitoring of cancer is the weakest in this region as population-based registries, plans of action and strategies are almost non-existent, which further adds to the agony. Targeting the modifiable factors like illiteracy regarding breast cancer symptoms and its early detection ameliorates the disease burden at the population level. With the refutation of the long-held belief that South Asian population are at a lower risk of breast cancer than the rest of the world [4], studies assessing the level of awareness and the state of preparedness are deemed further essential.

A bitter truth - Nepal has no national registries for cancer and the reported prevalence of cancer varies with different studies [5]. A hospital based study suggests that knowledge regarding breast cancer is low [6], despite it being the second most common cancer among women in Nepal [7]. The incidence of breast cancer is high among younger, premenopausal women; most of the cases being diagnosed at an advanced stage - when the likelihood of successful treatment is very low [8,9]. Clinical evidence reveals that breast cancer at a younger age has a greater likelihood of death owing to delayed diagnosis of the disease [10]. Therefore, higher rates of breast cancer in younger age demand early intervention.
Interventions promoting healthy behaviors and practices in early adolescence have a great role in preventing breast cancer as some of these behaviors are developed at this stage of life. Targeting adolescents is crucial for the success of any prevention efforts, also because they constitute a major proportion of population. Adolescent students are very receptive to information [11], and therefore, healthy behaviors established at this phase of life are most likely to be continued [12]. Similarly, the role of men in health service provision and decision making is well noted [13]. However, very few studies have considered assessing men's knowledge and awareness in relation to breast cancer [13-15].

In light of the evidences mentioned above, this study aims to explore the literacy of breast cancer risk factors, curability and its symptoms among the higher secondary students of Western Nepal. We focus on the difference in knowledge by sociodemographic factors, including gender.

\section{Methods \\ Study design and setting}

A cross-sectional study among the higher secondary students of Parbat district of Nepal was conducted. Parbat is a hilly district in Western Nepal with an area of $494 \mathrm{~km}^{2}$, population of 146,590 in 2011 of which 29,312 are aged 14-22 years and 12,645 attend a school [16]. Districts in Nepal have lower administrative divisions known as ilakas (sub-districts) and Parbat district consists of 11 such ilakas. Parbat represents a typical Nepalese hilly community with shades of both the urban and the rural lifestyles.

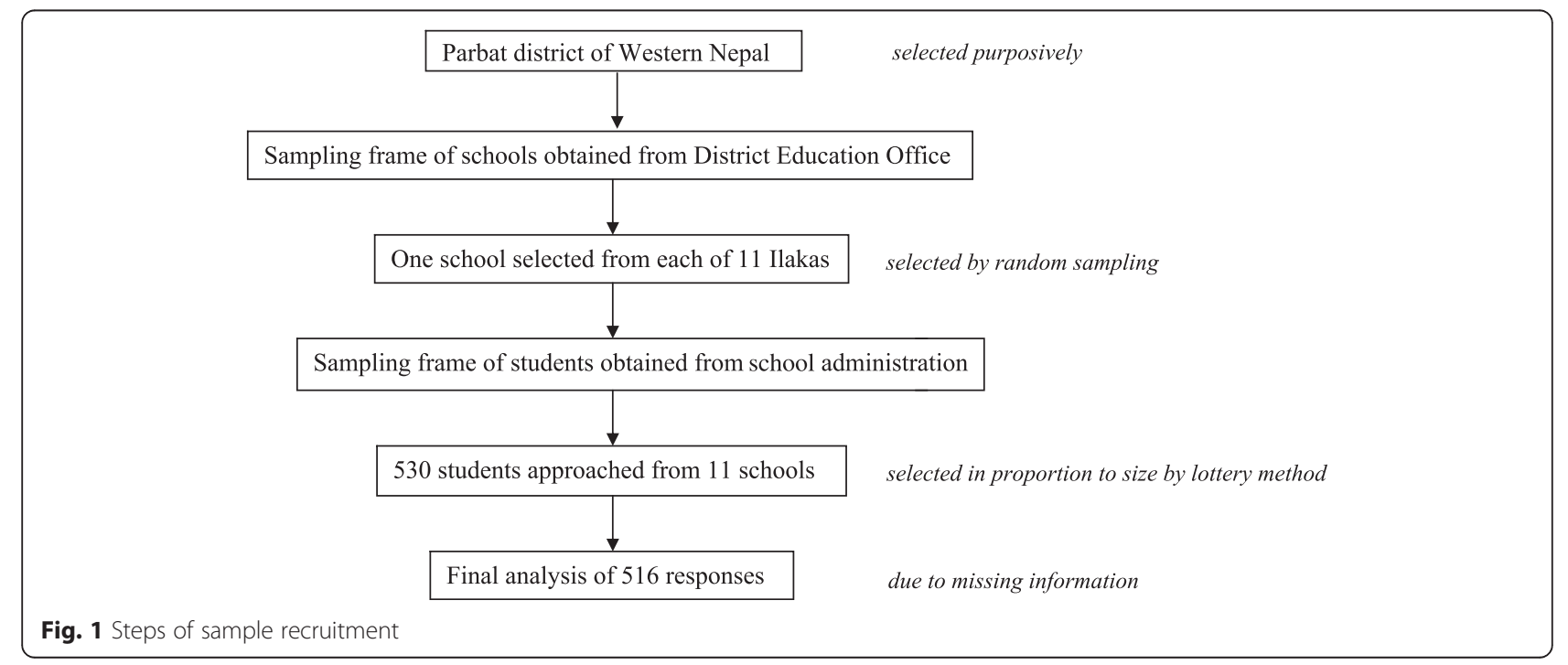


Table 1 Characteristics of participants and their knowledge level

\begin{tabular}{|c|c|c|c|c|}
\hline Characteristics & Total & Poor knowledge $e^{a}$ & Good knowledge ${ }^{a}$ & $p$-value ${ }^{\mathrm{b}}$ \\
\hline \multicolumn{5}{|l|}{ Age (years) } \\
\hline \multicolumn{5}{|c|}{ Mean $\pm S D=16.92 \pm 1.13$ years } \\
\hline $14-16$ years & $185(35.9)$ & $93(50.3)$ & $92(49.7)$ & \multirow[t]{3}{*}{0.849} \\
\hline $17-19$ years & $321(62.2)$ & $168(52.3)$ & $153(47.7)$ & \\
\hline 20-22 years & $10(1.9)$ & $5(50.0)$ & $5(50.0)$ & \\
\hline \multicolumn{5}{|l|}{ Sex } \\
\hline Male & $233(45.2)$ & $102(43.8)$ & $131(56.2)$ & \multirow[t]{2}{*}{$0.045^{*}$} \\
\hline Female & $283(54.8)$ & $149(52.7)$ & $134(47.3)$ & \\
\hline \multicolumn{5}{|l|}{ Ethnicity } \\
\hline Brahmin/Chhetri & $368(71.3)$ & $185(50.3)$ & $183(49.7)$ & \multirow[t]{4}{*}{0.440} \\
\hline Aadiwasi/Janajati & 65 (12.6) & $26(40.0)$ & $39(60.0)$ & \\
\hline Dalit & $47(9.1)$ & $24(51.1)$ & $23(48.9)$ & \\
\hline Others & $36(7.0)$ & $16(44.4)$ & $20(55.6)$ & \\
\hline \multicolumn{5}{|l|}{ Religion } \\
\hline Hindu & $490(95.0)$ & $239(48.8)$ & $251(51.2)$ & \multirow[t]{2}{*}{0.794} \\
\hline Others & $26(5.0)$ & $12(46.2)$ & $14(53.8)$ & \\
\hline \multicolumn{5}{|l|}{ Grade } \\
\hline 11 & $196(38.0)$ & $94(48.0)$ & $102(52.0)$ & \multirow[t]{2}{*}{0.808} \\
\hline 12 & $320(62.0)$ & $157(49.1)$ & $163(50.9)$ & \\
\hline \multicolumn{5}{|l|}{ Tobacco use } \\
\hline Yes & $10(1.9)$ & $7(70.0)$ & $3(30.0)$ & \multirow[t]{2}{*}{0.172} \\
\hline No & $506(98.1)$ & $244(48.2)$ & $262(51.8)$ & \\
\hline \multicolumn{5}{|l|}{ Alcohol consumption } \\
\hline Yes & $9(1.7)$ & $5(55.6)$ & $4(44.4)$ & \multirow[t]{2}{*}{0.676} \\
\hline No & $507(98.3)$ & $246(48.5)$ & $261(51.5)$ & \\
\hline \multicolumn{5}{|l|}{ Type of family } \\
\hline Nuclear family & $378(73.3)$ & $183(48.4)$ & $195(51.6)$ & \multirow[t]{2}{*}{0.862} \\
\hline Extended family & $138(26.7)$ & $68(49.3)$ & $70(50.7)$ & \\
\hline \multicolumn{5}{|l|}{ Monthly family income } \\
\hline$\leq$ NPR 20,000 ( $\leq 20$ USD) & $358(69.4)$ & $176(49.2)$ & $182(50.8)$ & \multirow[t]{2}{*}{0.723} \\
\hline >NPR 20,000 (>20 USD) & $158(30.6)$ & $75(47.5)$ & $83(52.5)$ & \\
\hline \multicolumn{5}{|l|}{ Family history of cancer } \\
\hline Present & $104(20.2)$ & $42(40.4)$ & $62(59.6)$ & \multirow[t]{2}{*}{0.059} \\
\hline Absent & $412(79.8)$ & $209(50.7)$ & $203(49.3)$ & \\
\hline
\end{tabular}

Data are frequency (percentage)

${ }^{\mathrm{a}}$ Row percentage

${ }^{\mathrm{b}} p$-value derived from the chi-square test of association

${ }^{*} p<0.05$

\section{Sample size and selection of participants}

Considering that $25 \%$ of students are acquainted to the risk factors and symptoms of breast cancer [17], a sample size of 520 was optimal for a desired $95 \%$ confidence interval, considering $4 \%$ allowable error and $15 \%$ nonresponse rate. The process of sampling involved random selection of a school from each ilaka. In the second stage, the principals of respective schools were contacted, briefed about the study objectives and asked for their permission to collect data. In order to attain the desired sample size, the number of students to be recruited from each school in proportion to the enrollment size was determined. Lottery method was used to randomly select the allocated number of students from attendance register at each school. Out of 530 students approached, none declined from participation in 
Table 2 Response of participants to statements on risk factors of breast cancer

\begin{tabular}{|c|c|c|c|c|c|}
\hline Statement & Response & Total $(n=516)$ & Male $(n=233)$ & Female $(n=283)$ & $p$-value \\
\hline \multirow{3}{*}{$\begin{array}{l}\text { Early menarche in a woman increases } \\
\text { the risk of developing breast cancer. }\end{array}$} & Yes & $99(19.2)$ & $59(25.3)$ & $40(14.1)$ & \multirow[t]{3}{*}{$0.006^{*}$} \\
\hline & No & $106(20.5)$ & $44(18.9)$ & $62(21.9)$ & \\
\hline & Don't know & $311(60.3)$ & $130(55.8)$ & $181(64.0)$ & \\
\hline \multirow{3}{*}{$\begin{array}{l}\text { Women who have delayed menopause } \\
\text { are at greater risk of breast cancer. }{ }^{a}\end{array}$} & Yes & $146(28.3)$ & $84(36.1)$ & $62(21.9)$ & \multirow[t]{3}{*}{$0.002^{* *}$} \\
\hline & No & $62(12.0)$ & $24(10.3)$ & $38(13.4)$ & \\
\hline & Don't know & $308(59.7)$ & $125(53.6)$ & $183(64.7)$ & \\
\hline \multirow{3}{*}{$\begin{array}{l}\text { Use of oral contraceptives increases a } \\
\text { woman's risk of developing breast cancer. }{ }^{a}\end{array}$} & Yes & $184(35.7)$ & $84(36.1)$ & $100(35.3)$ & \multirow[t]{3}{*}{0.876} \\
\hline & No & $63(12.2)$ & $30(12.9)$ & $33(11.7)$ & \\
\hline & Don't know & $269(52.1)$ & $119(51.0)$ & $150(53.0)$ & \\
\hline \multirow{3}{*}{$\begin{array}{l}\text { Breastfeeding reduces the risk of } \\
\text { developing breast cancer. }{ }^{\text {a }}\end{array}$} & Yes & $255(49.4)$ & $123(52.8)$ & $132(46.6)$ & \multirow[t]{3}{*}{0.381} \\
\hline & No & $69(13.4)$ & $29(12.4)$ & $40(14.1)$ & \\
\hline & Don't know & $192(37.2)$ & $81(34.8)$ & $111(39.3)$ & \\
\hline \multirow{3}{*}{$\begin{array}{l}\text { Physical exercise reduces the risk } \\
\text { of developing breast cancer. }{ }^{\text {a }}\end{array}$} & Yes & $322(62.4)$ & $154(66.1)$ & $168(59.4)$ & \multirow[t]{3}{*}{0.287} \\
\hline & No & $43(8.3)$ & $18(7.7)$ & $25(8.8)$ & \\
\hline & Don't know & $151(29.3)$ & $61(26.2)$ & $90(31.8)$ & \\
\hline \multirow{3}{*}{$\begin{array}{l}\text { A hard blow to the breast may cause } \\
\text { a woman to get breast cancer later in life. }\end{array}$} & Yes & $181(35.1)$ & $81(34.8)$ & $100(35.3)$ & \multirow[t]{3}{*}{0.565} \\
\hline & No & $77(14.9)$ & $39(16.7)$ & $38(13.4)$ & \\
\hline & Don't know & $258(50.0)$ & $113(48.5)$ & $145(51.3)$ & \\
\hline \multirow{3}{*}{$\begin{array}{l}\text { The constant irritation of a tight bra can, } \\
\text { over time, cause breast cancer.b }\end{array}$} & Yes & $129(25.0)$ & $49(21.0)$ & $80(28.3)$ & \multirow[t]{3}{*}{0.121} \\
\hline & No & $89(17.2)$ & $39(16.7)$ & $50(17.7)$ & \\
\hline & Don't know & $298(57.8)$ & $145(62.3)$ & $153(54.0)$ & \\
\hline \multirow{3}{*}{$\begin{array}{l}\text { In some women, being overweight increases } \\
\text { the risk of developing breast cancer. }\end{array}$} & Yes & $188(36.4)$ & $101(43.3)$ & $87(30.7)$ & \multirow[t]{3}{*}{$0.011^{*}$} \\
\hline & No & $86(16.7)$ & $33(14.2)$ & $53(18.7)$ & \\
\hline & Don't know & $242(46.9)$ & $99(42.5)$ & $143(50.6)$ & \\
\hline \multirow{3}{*}{$\begin{array}{l}\text { A woman who bears her first child before } \\
\text { the age of } 30 \text { is more likely to develop breast } \\
\text { cancer than a woman who bears her first } \\
\text { child after the age of } 30 .^{b}\end{array}$} & Yes & $131(25.4)$ & $69(29.6)$ & $62(21.9)$ & \multirow[t]{3}{*}{0.067} \\
\hline & No & $282(54.7)$ & $49(21.0)$ & $54(19.1)$ & \\
\hline & Don't know & $103(19.9)$ & $115(49.4)$ & $167(59.0)$ & \\
\hline \multirow{3}{*}{$\begin{array}{l}\text { Women with no known risk factors for } \\
\text { breast cancer rarely get breast cancer. }\end{array}$} & Yes & $167(32.4)$ & $84(36.1)$ & $83(29.3)$ & \multirow[t]{3}{*}{0.202} \\
\hline & No & $60(11.6)$ & $23(9.9)$ & $37(13.1)$ & \\
\hline & Don't know & $289(56.0)$ & $126(54.0)$ & $163(57.6)$ & \\
\hline \multirow{3}{*}{$\begin{array}{l}\text { Some types of fibrocystic breast disease } \\
\text { (noncancerous breast lumps) increase a } \\
\text { woman's risk of breast cancer. }{ }^{\text {a }}\end{array}$} & Yes & $292(56.6)$ & $123(52.8)$ & $169(59.7)$ & \multirow[t]{3}{*}{0.074} \\
\hline & No & $32(6.2)$ & $20(8.6)$ & $12(4.2)$ & \\
\hline & Don't know & $192(37.2)$ & 90 (38.6) & $102(36.1)$ & \\
\hline \multirow{3}{*}{$\begin{array}{l}\text { Breast cancer is more common in } 65 \text {-year-old } \\
\text { women than in } 40 \text {-year-old women. }{ }^{\text {a }}\end{array}$} & Yes & $115(22.3)$ & $52(22.3)$ & $63(22.3)$ & \multirow[t]{3}{*}{0.054} \\
\hline & No & $160(31.0)$ & $84(36.1)$ & $76(26.9)$ & \\
\hline & Don't know & $241(46.7)$ & $97(41.6)$ & $144(50.8)$ & \\
\hline The most frequently occurring cancer in women is breast cancer. ${ }^{a}$ & Yes & $253(49.0)$ & $113(48.4)$ & $140(49.5)$ & $0.018^{*}$ \\
\hline & No & $107(20.7)$ & $60(25.8)$ & $47(16.6)$ & \\
\hline & Don't know & $156(30.3)$ & $60(25.8)$ & $96(33.9)$ & \\
\hline Women over age 70 rarely get breast cancer. ${ }^{\text {b }}$ & Yes & $159(30.8)$ & $68(29.2)$ & $91(32.2)$ & 0.434 \\
\hline & No & $88(17.1)$ & $45(19.3)$ & $43(15.2)$ & \\
\hline & Don't know & $269(52.1)$ & $120(51.5)$ & $149(52.6)$ & \\
\hline Most breast lumps are cancerous. ${ }^{b}$ & Yes & $218(42.2)$ & $96(41.2)$ & $122(43.1)$ & 0.064 \\
\hline
\end{tabular}


Table 2 Response of participants to statements on risk factors of breast cancer (Continued)

\begin{tabular}{lllll}
\hline No & $87(16.9)$ & $49(21.0)$ & $38(13.4)$ & $123(43.5)$ \\
\hline
\end{tabular}

\author{
Data are frequency (percentage) \\ ${ }^{\text {a }}$ Statement is true \\ ${ }^{\mathrm{b}}$ Statement is false \\ ${ }^{c} p$-value derived from the chi-square test of association \\ ${ }^{*} p<0.05,{ }^{* *} p<0.005$
}

the study. Complete information was obtained from 516 participants and the responses of 14 participants were discarded because of missing information (Fig. 1).

\section{Data collection}

The study objectives along with the correct technique to provide responses were explained and the questionnaires were distributed to the students. PMB, KT, SD, SB and $\mathrm{RD}$ carried out the data collection at the regular classroom of the students. Teachers were not present in the classroom at the time of enumeration, and the students were seated such that anonymity of responses was assured.

The Comprehensive Breast Cancer Knowledge Test (CBCKT) was used, with some contextual modifications. The original tool consists 20 items (12 statements on general awareness and 8 statements on curability), with reliability coefficient of 0.71 [18]. Two statements from the original tool were removed as they were specific to women of United States. An addition of 5 statements was made to the questionnaire considering the recently available evidences on the effects of early menarche, delayed menopause, physical activity, oral contraceptive pills and breastfeeding on breast cancer [19, 20]. Response alternatives included 'Yes, 'No' and 'Don't know' (see Additional file 1). The questionnaire, which was in Nepali language, was previously pretested to a sample of 40 students from a higher secondary school of Kathmandu district, and was reviewed for language and comprehension.

Demographic information (age, sex, ethnicity and religion) and status of tobacco and alcohol consumption were obtained from the participants. Information regarding the family structure, family history of cancer and monthly family income of the students were also recorded. Students were asked for their perspectives on the adequacy of the breast cancer information in their curriculum. Sources of information regarding breast cancer and breast cancer symptoms, that were originally not a part of the CBCKT, were also recorded. Students were provided with a list of symptoms as options, and were asked to select potential symptoms of breast cancer.

\section{Data analysis}

Data entry was carried out in EpiData 3.1 while all the analyses were performed in SPSS version 21
(SPSS, Chicago, Illinois, USA). Frequency and percentage were generated for responses to knowledge statements and socio-demographic variables. For a correct response to any of the 23 items on the questionnaire, a score of 1 was provided while an incorrect response or a response indicating 'Don't know' was scored 0. A composite score of all the items combined was calculated which could range from $0-$ 23. Median value of the composite score was 7.0 (slightly greater than the mean: 6.65). Knowledge score, after dichotomization taking the median as the cut-off, was grouped into two categories: 'good knowledge' and 'poor knowledge'. Comparison of knowledge level with personal characteristics of students was made using chi-squared test, $p$-value $<0.05$ taken as statistically significant.

\section{Ethics}

This study was approved by the Department of Community Medicine and Public Health (DCMPH), Maharajgunj Medical Campus (Ref. No. 105-072-073). During the ethical review, the need for parental consent for participants aged $<16$ years was waived by the DCMPH owing to the non-interventional and non-invasive study design. Prior to data collection, permission was obtained from the District Education Office and school principals. We obtained written informed consent from all the participants after explaining the study objectives. No financial incentive was provided to the participants. Participants were assured of anonymity and were informed of their right to voluntary participation and withdraw from the study at any stage.

\section{Results \\ Characteristics of participants}

Participants belonged to an age group of 14 to 22 years with mean of 16.92 years $(S D=1.13)$. More than half of the participants $(54.8 \%)$ were female, $71.3 \%$ were Brahmin/Chhetri and $95.0 \%$ were Hindu. A majority of the participants $(62.0 \%)$ studied in grade $12,1.9 \%$ were tobacco users and $1.7 \%$ consumed alcohol. One in every five participants $(20.2 \%)$ had a family history of cancer. Knowledge of students varied significantly with gender $\left(\chi^{2}=4.02, p=0.045\right)$ (Table 1$)$.

Nearly half of the participants $(47.1 \%)$ perceived that the school curriculum inadequately informed them on breast cancer. One-in-four students (24.8\%) had heard 
Table 3 Response of participants to statements on curability of breast cancer

\begin{tabular}{|c|c|c|c|c|c|}
\hline Statement & Response & Total $(n=516)$ & Male $(n=233)$ & Female $(n=283)$ & $p$-value \\
\hline \multirow{3}{*}{$\begin{array}{l}\text { For many women, breast cancer can now be } \\
\text { successfully treated without breast removal (mastectomy). }{ }^{\text {a }}\end{array}$} & Yes & $201(39.0)$ & 97 (41.6) & $104(36.7)$ & \multirow[t]{3}{*}{$0.035^{*}$} \\
\hline & No & $94(18.2)$ & $50(21.5)$ & $44(15.5)$ & \\
\hline & Don't know & $221(42.8)$ & $86(36.9)$ & $135(47.8)$ & \\
\hline \multirow{3}{*}{$\begin{array}{l}\text { By the time a cancerous breast lump is painful, } \\
\text { it is too late to be successfully treated. }\end{array}$} & Yes & $249(48.3)$ & $122(52.4)$ & $127(44.9)$ & \multirow[t]{3}{*}{0.142} \\
\hline & No & $66(12.8)$ & $31(13.3)$ & $35(12.4)$ & \\
\hline & Don't know & $201(38.9)$ & $80(34.3)$ & $121(42.7)$ & \\
\hline \multirow{3}{*}{$\begin{array}{l}\text { If all lymph glands around the breast and } \\
\text { under the arm are not removed, breast } \\
\text { cancer cannot be cured. }{ }^{\text {b }}\end{array}$} & Yes & $109(21.1)$ & $59(25.3)$ & $50(17.7)$ & \multirow[t]{3}{*}{0.098} \\
\hline & No & $76(14.7)$ & $31(13.3)$ & 45 (15.9) & \\
\hline & Don't know & $331(64.2)$ & $143(61.4)$ & $188(66.4)$ & \\
\hline \multirow{3}{*}{$\begin{array}{l}\text { Breast cancer is sometimes treated successfully by } \\
\text { removal of the lump (lumpectomy) and radiation therapy. }\end{array}$} & Yes & $221(42.8)$ & 89 (38.2) & $132(46.6)$ & \multirow[t]{3}{*}{0.100} \\
\hline & No & $57(11.0)$ & $31(13.3)$ & $26(9.2)$ & \\
\hline & Don't know & $238(46.2)$ & $113(48.5)$ & $125(44.2)$ & \\
\hline \multirow{3}{*}{$\begin{array}{l}\text { Breast cancer is less likely to be cured in women } \\
\text { with a family history of breast cancer than in women } \\
\text { with no family history of breast cancer. }\end{array}$} & Yes & $151(29.3)$ & 78 (33.5) & $73(25.8)$ & \multirow[t]{3}{*}{0.155} \\
\hline & No & $124(24.0)$ & $54(23.2)$ & $70(24.7)$ & \\
\hline & Don't know & $241(46.7)$ & $101(43.3)$ & $140(49.5)$ & \\
\hline \multirow{3}{*}{$\begin{array}{l}\text { By the time a woman can feel a cancerous breast } \\
\text { lump, it is too late to treat it effectively. }\end{array}$} & Yes & $237(45.9)$ & $113(48.5)$ & $124(43.8)$ & \multirow[t]{3}{*}{0.132} \\
\hline & No & 87 (16.9) & 44 (18.9) & $43(15.2)$ & \\
\hline & Don't know & $192(37.2)$ & 76 (32.6) & $116(41.0)$ & \\
\hline \multirow{3}{*}{$\begin{array}{l}\text { Even if breast cancer is caught very early, the } \\
\text { chances for cure are much better if the whole } \\
\text { breast is removed. }\end{array}$} & Yes & $204(39.5)$ & $97(41.6)$ & $107(37.8)$ & \multirow[t]{3}{*}{0.053} \\
\hline & No & 96 (18.6) & $51(21.9)$ & 45 (15.9) & \\
\hline & Don't know & $216(41.9)$ & 85 (36.5) & $131(46.3)$ & \\
\hline \multirow{3}{*}{$\begin{array}{l}\text { Even if detected and treated early, a woman with } \\
\text { breast cancer is unlikely to live a normal life span. }\end{array}$} & Yes & $185(35.9)$ & $73(31.3)$ & $112(39.6)$ & \multirow[t]{3}{*}{0.118} \\
\hline & No & $203(39.3)$ & 95 (40.8) & $108(38.2)$ & \\
\hline & Don't know & $128(24.8)$ & $65(27.9)$ & $63(22.2)$ & \\
\hline
\end{tabular}

Data are frequency (percentage)

${ }^{\text {a }}$ Statement is true

${ }^{b}$ Statement is false

${ }^{c} p$-value derived from the chi-square test of association

${ }^{*} p<0.05$

of Breast Self Examination (BSE) while 29.8 \% had heard of mammography. Only $4.8 \%$ of the students responded correctly to at least half of the 23 items, and $1.4 \%$ did not respond correctly to any of the items on risk factors and curability.

\section{Risk factors of breast cancer}

Breast cancer was correctly identified as the most common cancer in women by $49.0 \%$ (male: $48.4 \%$; female: $49.5 \%$ ) of the students. Regarding the knowledge of risk factors of breast cancer, most of them (49.4 \%-male: $52.8 \%$; female: $46.6 \%$ ) were aware of the protective role of breastfeeding and exercise (62.4 \%- male: $66.1 \%$; female: $59.4 \%$ ). Respondents correctly reported risk factors of breast cancer like early menarche (19.2 \%- male: $25.3 \%$; female: $14.1 \%$ ), delayed menopause (28.3 \%- male: $36.1 \%$; female: $21.9 \%$ ), use of oral contraceptives (35.7\%male: $36.1 \%$; female: $35.3 \%$ ) and being overweight
(36.4 \%- male: $43.3 \%$; female: $30.7 \%$ ). Similarly, $25.4 \%$ (male: $29.6 \%$; female: $21.9 \%$ ) of the students incorrectly reported childbearing before age of 30 to be a risk factor for breast cancer. Further, 22.3 \% (male: 22.3 \%; female: $22.3 \%$ ) of them were aware that risk of breast cancer gets higher in older age. Only 11.6 \% (male: $9.9 \%$; female: $13.1 \%$ ) of the students correctly responded that a woman without any known risk factor may also develop breast cancer later in her life. Increased risk of breast cancer with the occurrence of some fibrocystic breast disease was correctly reported by $56.6 \%$ (male: $52.8 \%$; female: $59.7 \%$ ) of the students.

Students had false perception that hard blow to breast (35.1\%-male: $34.8 \%$; female: $35.3 \%$ ) and irritation caused by a brassiere (25.0\%-male: $21.0 \%$; female: $28.3 \%$ ) triggers breast cancer. Similarly, $42.2 \%$ (male: $41.2 \%$; female: $43.1 \%$ ) wrongly responded that most of the lumps in breast are cancerous. Also, $30.8 \%$ (male: $29.2 \%$; female: $32.2 \%$ ) were 
Table 4 Knowledge of breast cancer symptoms

\begin{tabular}{|c|c|c|c|c|c|c|}
\hline \multirow[t]{2}{*}{ Symptoms $^{a}$} & \multicolumn{2}{|c|}{ Total $(n=516)$} & \multicolumn{2}{|c|}{ Male $(n=233)$} & \multicolumn{2}{|c|}{ Female $(n=283)$} \\
\hline & Yes & No & Yes & No & Yes & No \\
\hline Pain in breast & $120(23.3)$ & $396(76.7)$ & $55(23.6)$ & $178(76.4)$ & $65(23.0)$ & $218(77.0)$ \\
\hline Change in breast shape & $103(20.0)$ & $413(80.0)$ & $48(20.6)$ & $185(79.4)$ & $55(19.4)$ & $228(80.6)$ \\
\hline Discharge of pus & $73(14.1)$ & $443(85.9)$ & $36(15.5)$ & $197(84.5)$ & $37(13.1)$ & $246(86.9)$ \\
\hline Painless lump in breast & $59(11.4)$ & 457 (88.6) & $25(10.7)$ & $208(89.3)$ & $34(12.0)$ & $249(88.0)$ \\
\hline Increase in the number of breast lumps & $44(8.5)$ & $472(91.5)$ & $20(8.6)$ & $213(91.4)$ & $24(8.5)$ & $259(91.5)$ \\
\hline Weight loss & $43(8.3)$ & $473(91.7)$ & $26(11.2)$ & $207(88.8)$ & $17(6.0)$ & $266(94.0)$ \\
\hline Nausea & $18(3.5)$ & $498(96.5)$ & $11(4.7)$ & $222(95.3)$ & $7(2.5)$ & 276 (97.5) \\
\hline
\end{tabular}

${ }^{\text {a Multiple-response }}$

Data are frequency (percentage)

misinformed that breast cancer is rare in older women (aged $>70$ years) (Table 2 ).

\section{Curability of breast cancer}

About two in every five (39.0 \%- male: $41.6 \%$; female: $36.7 \%)$ respondents were informed that modalities of treatment other than mastectomy are also available and $42.8 \%$ (male: $38.2 \%$; female: $46.6 \%$ ) knew that lumpectomy and radiation therapy are available alternatives for treatment of breast cancer. Less than half (48.3\%- male: $52.4 \%$; female: $44.9 \%$ ) of the students held a misperception that successful treatment of cancerous breast lump after it becomes painful is next to impossible while $21.1 \%$ (male: $25.3 \%$; female: $17.7 \%$ ) believed that treatment of breast cancer without removal of all the lymph glands around breast and under the arm is not possible.

A significant proportion (45.9\%- male: $48.5 \%$; female: $43.8 \%)$ of the students believed that effective treatment of breast cancer after it can be felt by a woman is not possible, and $39.5 \%$ (male: $41.6 \%$; female: $37.8 \%$ ) had the belief that the chances of successful treatment is better upon removal of the whole breast. Similarly, $29.3 \%$ (male: $33.5 \%$; female: $25.8 \%$ ) of the participants believed that having a family history of breast cancer decreased the likelihood of breast cancer being cured.
Also, 35.9 \% (male: $31.3 \%$; female: $39.6 \%$ ) thought that despite the early detection and treatment, a woman with breast cancer cannot live a normal life (Table 3).

\section{Symptoms of breast cancer}

Only $39.5 \%$ of the students chose at least one symptom of breast cancer from the list provided. Pain in the breast was the most commonly suggested symptom, reported by $23.6 \%$ of male students and $23.0 \%$ of female students. Change in shape of the breast was the second most common symptom reported; $20.6 \%$ of males and $19.4 \%$ of females mentioned it (Table 4 ).

\section{Source of information regarding breast cancer}

The majority of students (70.9\%) reported television/ radio as the most common source of information on breast cancer. Other sources, reported in descending order of frequency were: teachers $(26.0 \%)$, textbooks (25.8\%), health workers (25.2 \%), friends/relatives (24.2\%), newspapers (23.6 \%) and poster/pamphlets (10.5 \%) (Fig. 2).

\section{Discussion}

Most of the students had misleading information about age, early menarche and delayed menopause as the risk

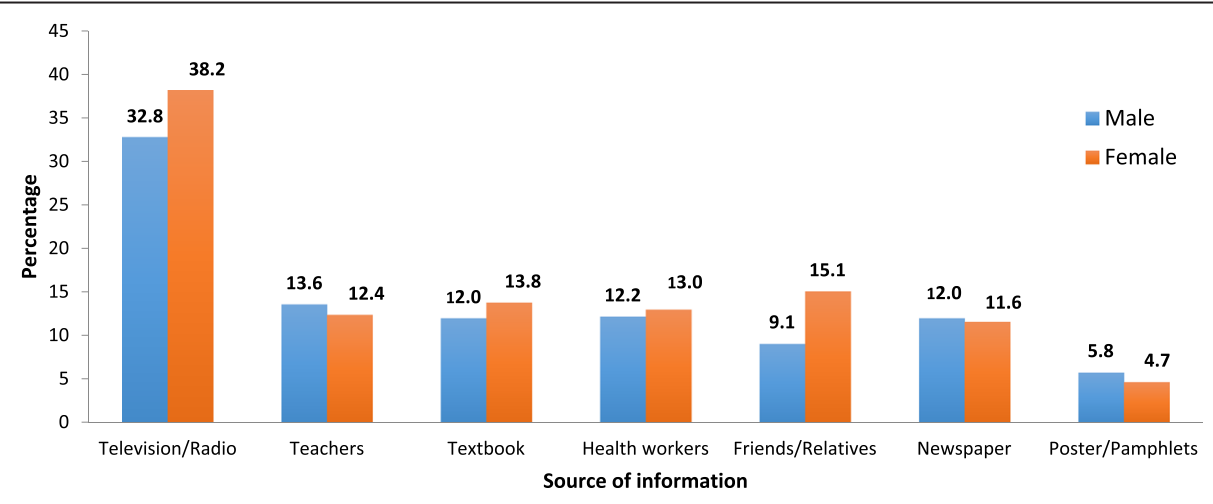

Fig. 2 Sources of information 
factors. More than half of the respondents, regardless of their sex, were not well-informed about the risk possessed by regular intake of oral contraceptive pills (OCPs).

Many respondents did not know that breast cancer can be prevented at an early stage if diagnosed properly. A substantial proportion of students had myths that early detection of breast cancer has no benefits on success of treatment, and hard blow to the breast causes breast cancer. This depicts the abysmal level of awareness and ignorance of risk factors in the community. Being less aware about the screening methods and treatment modalities can be a barrier to seek screening and detection services thus causing a delay in diagnosis and treatment. In breast cancer, the more advanced the disease, the lower the chance of survival [21].

Age, educational level, household income and family history of breast cancer are reported to be significantly associated with the knowledge level [22, 23]. However, the study did not reveal such association. The study shows that male students were better informed of breast cancer risk factors and curability than their female counterparts. This finding is consistent with the findings of a previous study by McMenamin et al. [15]. Though females are at a higher risk of the disease, they are generally less informed than the male population. This apparent difference in knowledge between the genders might be accounted for difference in access to health information between genders, and social restrictiveness.

By knowing a simple measure like BSE, women can decrease the risk of breast cancer by early detection and prompt treatment. The study showed that less than onefourth of the respondents had heard of BSE. Of the people who have heard of BSE, few know the correct practice $[24,25]$. Practice of BSE, as explained by the Health Belief Model, is shaped by the interaction of perceived susceptibility, benefits, perceived seriousness, self-efficacy and perceived barriers $[25,26]$. So, with fewer percentage of respondents who have merely heard of BSE, one can easily imagine that, in this study, students who can actually perform it might be negligible.

The most common source of information related to the breast cancer was Television/Radio which is similar to the findings reported by previous studies [27, 28]. This stresses that health education programs through Television/Radio can be most effective in promoting and modifying healthy behavior in our study population. Teachers, Textbook, Health workers and Friends/relatives share similar but account for low percentage in the source of information.

Knowledge regarding the symptoms of breast cancer is of importance as a layman seeks health services depending on his/her literacy of these symptoms. In this study, only less than half of the students could mention at least one symptom of breast cancer. The three most commonly cited symptoms of breast cancer were pain in breast, change in breast shape and discharge of pus from the nipple. Our findings are consistent with a previous study conducted among Australian women, in which these three symptoms were reported by a major proportion of participants [29].

It is important to note that in most of the items, a high percentage of the students replied with a 'Don't know' response. This depicts that the students have no idea regarding the risk factors and curability of breast cancer. Further, nearly half of the students perceived existing school curriculum inadequate to be well-aware on breast cancer.

As higher secondary students are in age of making reproductive choices; they should, therefore, be aware about the risks linked with oral contraceptive use. While most of the biological risk factors are non-modifiable, some behaviors like use of oral contraceptive, physical exercise, breastfeeding and initiation of regular BSE at an early age can reduce the risk of developing breast cancer. There is a scope to promote BSE among the adolescent girls in schools when health education campaigns about breast cancer are launched in partnership with schools, parents and community organizations in our study population. As breast cancer screening is likely to increase flow of patients seeking care, any further effort for screening should come along with capacity building of hospitals in detection, treatment and care of people with potential cancers.

The result of this study found that students have a poor knowledge on many breast cancer risk factors, symptoms and curability. There is a need to boost knowledge of students, especially female students. National Health Education, Information and Communication Centre and concerned stakeholders should design awareness programs to sensitize women as well as men, family, and the general community about breast cancer and its early detection measures.

However, the study has few limitations. The instrument used for the assessment of knowledge has not been validated in the Nepalese context, so, room for questioning the construct validity of the tool is present. Besides, all the schools included in this study were public and were drawn from one hilly district of Nepal. This might limit the generalization of our findings to students from private schools and to other districts from the plains. Still, this study will be valuable to frame relevant awareness activities and to guide policy measures considering the context where no literature on breast cancer awareness is available.

\section{Conclusion}

This study demonstrates that students have poor knowledge on many breast cancer risk factors, symptoms and curability. Furthermore, most of the students had 
misleading information about age, early menarche, delayed menopause and use of OCPs as the risk factors. Many myths regarding curability of breast cancer were prevalent. Breast cancer literacy was significantly better among males in comparison to females. Future studies should particularly aim at identifying measures necessary to address the inadequate knowledge, along with the gaps in school curriculum.

\section{Additional file}

Additional file 1: Questionnaire. (PDF $56 \mathrm{~kb}$ )

\section{Abbreviations}

BSE: Breast Self Examination; CBCKT: Comprehensive Breast Cancer Knowledge Test; NPR: Nepalese Rupee; OCP: Oral Contraceptive Pills.

\section{Competing interests}

The authors declare that they have no competing interests.

\section{Authors' contributions}

PMB conceptualized the research work. PMB, KT, SD, SB and RD contributed in study design and field level data collection. PMB and KT carried out the data analysis. PMB, KT, SD and SB wrote the first draft of manuscript. PA and SRM contributed in literature review and interpretation of results. All the authors contributed in revision of the manuscript and agreed on final manuscript.

\section{Acknowledgements}

The authors thank all the students who participated in this study. We also thank Umesh Kumar Adhikari for help in data collection, and Dipika Neupane for comments on draft manuscript. We are grateful to Sneha Shakya and Jessica Ohland for English editing.

\section{Author details}

Maharajgunj Medical Campus, Institute of Medicine, Tribhuvan University, Kathmandu, Nepal. ${ }^{2}$ Unit of Health Promotion Research, University of Southern Denmark, Esbjerg, Denmark. ${ }^{3}$ Nepal Development Society (NEDS), Chitwan, Nepal. ${ }^{4}$ School of Population Health, University of Western Australia, Crawley, WA, Australia.

Received: 21 June 2015 Accepted: 14 February 2016

Published online: 18 February 2016

\section{References}

1. International Agency for Research on Cancer. World Cancer Report 2014 Geneva: World Health Organization; 2014.

2. Moore MA, Ariyaratne Y, Badar F, Bhurgri Y, Datta K, Mathew A, et al. Cancer epidemiology in South Asia-past, present and future. Asian Pac J Cancer Prev. 2010;11 Suppl 2:49-66.

3. Hortobagyi GN, de la Garza SJ, Pritchard K, Amadori D, Haidinger R, Hudis CA, et al. The global breast cancer burden: variations in epidemiology and survival. Clin Breast Cancer. 2005:6(5):391-401. doi:10.3816/CBC.2005.n.043.

4. The University of Sheffield. South Asian women should no longer be considered at low risk of breast cancer. 2013. http://www.sheffield.ac.uk/ news/nr/breast-cancer-risk-1.280243. Accessed 21 January 2016.

5. Mishra SR, Neupane D, Bhandari PM, Khanal V, Kallestrup P. Burgeoning burden of non-communicable diseases in Nepal: a scoping review. Global Health. 2015;11(1):32. doi:10.1186/s12992-015-0119-7.

6. Shrestha K. Breast cancer knowledge and screening practice among women visited to KIST medical college. Nepal Med Coll J. 2012;14(4):308-11.

7. Pradhananga KK, Baral M, Shrestha BM. Multi-institution hospital-based cancer incidence data for Nepal: an initial report. Asian Pac J Cancer Prev. 2009:10(2):259-62.

8. Thapa B, Singh Y, Sayami P, Shrestha UK, Sapkota R, Sayami G. Breast cancer in young women from a low risk population in Nepal. Asian Pac J Cancer Prev. 2013;14(9):5095-9. doi:10.7314/APJCP.2013.14.9.5095.
9. Acharya SC, Jha AK, Manandhar T. Clinical profile of patients presenting with breast cancer in Nepal. Kathmandu Univ Med J (KUMJ). 2012;10(39):3-7.

10. Schairer C, Mink PJ, Carroll L, Devesa SS. Probabilities of death from breast cancer and other causes among female breast cancer patients. J Natl Cancer Inst. 2004;96(17):1311-21. doi:10.1093/jnci/djh253.

11. Wallston KA, Wallston BA. Health locus of control scales. In: Lefcourt $H$, editor. Research with the locus of Control Construct, vol 1: assessment methods. New York: Academic; 1978.

12. Kaneda T, Naik R, Baldwin W. Noncommunicable diseases risk factors among young people in Africa: data availability and sources. Population Reference Bureau: Washington, USA; 2014

13. Chamot E, Perneger TV. Men's and women's knowledge and perceptions of breast cancer and mammography screening. Prev Med. 2002;34(3):380-5. doi:10.1006/pmed.2001.0999.

14. Mafuvadze B, Manguvo A, He J, Whitney SD, Hyder SM. Breast cancer knowledge and awareness among high school and college students in mid-Western USA. Int J Sci Educ. 2013;3(2):144-58. doi:10.1080/09500693. 2012.664294.

15. McMenamin M, Barry H, Lennon A-M, Purcell $H$, Baum M, Keegan D, et al. A survey of breast cancer awareness and knowledge in a Western population: lots of light but little illumination. Eur J Cancer. 2005;41(3):393-7. doi:10. 1016/j.ejca.2004.11.015.

16. Central Bureau of Statistics. National Population and Housing Census 2011 National Report. Kathmandu: Central Bureau of Statistics; 2011

17. Noreen M, Murad S, Furqan M, Sultan A, Bloodsworth P. Knowledge and awareness about breast cancer and its early symptoms among medical and non-medical students of Southern Punjab, Pakistan. Asian Pac J Cancer Prev. 2015;16(3):979-84. doi:10.7314/APJCP.2015.16.3.979.

18. Stager JL. The comprehensive breast cancer knowledge test: validity and reliability. J Adv Nurs. 1993;18(7):1133-40. doi:10.1046/j.1365-2648.1993. $18071133 x$

19. Nelson HD, Zakher B, Cantor A, Fu R, Griffin J, O'Meara ES, et al. Risk factors for breast cancer for women aged 40 to 49 years: a systematic review and meta-analysis. Ann Intern Med. 2012;156(9): 635-48, doi:10.7326/0003-4819-156-9-201205010-00006.

20. Collaborative Group on Hormonal Factors in Breast Cancer. Menarche, menopause, and breast cancer risk: individual participant meta-analysis, including 118964 women with breast cancer from 117 epidemiological studies. Lancet Oncol. 2012:13(11):1141-51. doi:10.1016/s14702045(12)70425-4.

21. Howlader N, Noone AM, Krapcho M, Garshell J, Miller D, Altekruse SF, et al SEER Cancer Statistics Review, 1975-2012. Bethesda: National Cancer Institute; 2014

22. Grunfeld EA, Ramirez AJ, Hunter MS, Richards MA. Women's knowledge and beliefs regarding breast cancer. Br J Cancer. 2002;86(9):1373-8. doi:10.1038/ sj.bjc. 6600260 .

23. Okobia MN, Bunker $\mathrm{CH}$, Okonofua FE, Osime U. Knowledge, attitude and practice of Nigerian women towards breast cancer: a cross-sectional study. World J Surg Oncol. 2006:4:11. doi:10.1186/1477-7819-4-11.

24. Chee H, Rashidah S, Shamsuddin K, Intan O. Factors related to the practice of breast self examination (BSE) and Pap smear screening among Malaysian women workers in selected electronics factories. BMC Womens Health. 2003;3(1):3. doi:10.1186/1472-6874-3-3.

25. Avci IA. Factors associated with breast self-examination practices and beliefs in female workers at a Muslim community. Eur J Oncol Nurs. 2008:12(2): 127-33. doi:10.1016/j.ejon.2007.11.006.

26. Cohen M, Azaiza F. Early breast cancer detection practices, health beliefs, and cancer worries in Jewish and Arab women. Prev Med. 2005;41(5-6):852-8. doi: 10.1016/j.ypmed.2005.07.001.

27. Boulos DN, Ghali RR. Awareness of breast cancer among female students at Ain Shams University, Egypt. Glob J Health Sci. 2013;6:154-61. doi:10.5539/ gjhs.v6n1p154.

28. Alwan NA, Al-Diwan JK, Wafa'M A-A, Eliessa RA. Knowledge, attitude \& practice towards breast cancer \& breast self examination in Kirkuk University, Iraq. Asian Pac J Reprod. 2012;1(4):308-11. doi:10.1016/S23050500(13)60098-6.

29. Jones SC, Gregory P, Nehill C, Barrie L, Luxford K, Nelson A, et al. Australian women's awareness of breast cancer symptoms and responses to potential symptoms. Cancer Causes Control. 2010;21(6):945-58. doi:10.1007/s10552010-9522-9. 